\title{
Association of rasgulla likeness with blood Grouping
}

\begin{abstract}
Objective of the present study was to correlate the Rasgulla likeness with Blood Grouping. It was the beneficial survey taken by the subject from different peoples and it provides the information to the subject about the recent research of Rasgulla likeness with the Blood Grouping. So these researches are the actual recent researches done by the subject.
\end{abstract}

Keywords: blood grouping, rasgulla, recent researches
Volume 7 Issue I - 2019

\author{
Muhammad Imran Qadir, Fatima Sattar \\ Bhutta \\ Institute of Molecular Biology and Biotechnology, Bahauddin \\ Zakariya University, Pakistan
}

\begin{abstract}
Correspondence: Fatima sattar Bhutta, Institute of Molecula Biology And Biotechnology, Bahauddin Zakariya University, Multan, Pakistan, Email fss66333@gmail.com
\end{abstract}

Received: January 02, 2019 | Published: February 15, 2019

\section{Introduction}

Blood group is basically defined as by presence and absence of a specific antigen on the surface of RBCs. There are two important blood group systems. One is the ABO blood group system and other is the Rh blood group system. The base of the blood group system is on agglutination reaction. When RBCs carry one or both antigens then they are exposed to antibodies that can interact with one another to form visible agglutination or clumping. Blood types are mainly based on the proteins and these proteins are called antigens. B negative and $\mathrm{O}$ negative are the rarest blood types in the world. $\mathrm{O}$ negative is the universal donor that means a person having the $\mathrm{O}$ negative blood group can donate the $\mathrm{RBCs}$ to everyone. A person having the $\mathrm{O}$ blood group have the thinnest blood, also that person have the strong immune system, and strong stomach acids and live the longest of all the blood types. Everyone have the ABO blood group system and the Rh factor which is either be positive or negative just like the eye or hair colour. There are the two antigens and the two antibodies in the ABO blood group system. In the start two there is the criss cross manner like a person having the antigen A then it must have the antibody $\mathrm{B}$ and if the person having the antigen B then it must have the antibody A. our blood is inherited from our parents. Rh blood group system is one of the thirty five known human blood group system. It's is the second most important type after the ABO blood group system. The term Rh factor have the two types when there is the presence of the protein then it's called the Rh positive. While there is the lack of the protein then it's called Rh negative. Rh positive is the most common blood group type.

Das of Kolkata invented the Rasgulla. Rasgulla was invented in the holy city of puri back in the thirteenth century. For the preparation of Rasgulla, the cheese which is also known as chhena mixture formed in the small balls. After the simmering of these balls these are converted in the sugar syrup. Rasgullas can also be prepared by the use of pressure cooker or oven. By adding a drop of rose water that is used which helps to enhance the taste and the flavour. Some Rasgullas are softer and creamish in colour. Some are whitish and rubbery. Typically a hundred gram serving of Rasgulla contains one hundred and eighty six calories out of them about one hundred and fifty three calories are in the form of carbohydrates, it also contains round about 1.86 grams of fats and about four grams of proteins. Rasgulla can be stored at room temperature for about three days. They will not be spoiled due to high sugar content in the syrup. Sugar used in it acts as a preservationist always safer to store and leftovers in refrigerator and Rasgullas can be stored in refrigerator for about two weeks.

\section{Objective of the present study was correlate blood grouping with rasgulla}

\section{Material and methods}

\section{Blood grouping}

We took consent from the subject. First of all a prick was made on our finger and the blood comes out from it. Then a slide was taken and three drops of blood on three different points are to be identified at three different spots on these three points. The antibodies were put into these spot on the first spot of the blood antibody A was put on the second antibody B and on the third antibody D. Then mix them. The solution was formed that was of blood and antibody. The agglutination reaction was taken that showed that which type of blood was used. ${ }^{1,2}$

Table I Rasgulla likeness with blood Grouping

\begin{tabular}{|c|c|c|c|c|c|c|c|c|}
\hline & \multicolumn{2}{|l|}{ Male } & \multicolumn{2}{|c|}{ Female } & \multicolumn{2}{|c|}{ Male } & \multicolumn{2}{|c|}{ Female } \\
\hline & Yes & Percentage & Yes & $\%$ & No & $\%$ & No & $\%$ \\
\hline $\mathrm{A}+$ & 11 & $11 \div 175 \times 100=6.28$ & 14 & $14 \div 175 \times 100=8$ & 1 & $1 \div 175 \times 100=0.57$ & 6 & $6 \div 175 \times 100=3.42$ \\
\hline A- & 1 & $1 \div 175 \times 100=5.84$ & 1 & $1 \div 175 \times 100=0.57$ & 0 & $0 \div 175 \times 100=0$ & 0 & $0 \div 175 \times 100=0$ \\
\hline $\mathrm{B}+$ & 9 & $9 \div 175 \times 100=5.14$ & 33 & $32 \div 175 \times 100=18.28$ & 1 & $1 \div 175 \times 100=0.57$ & 17 & $17 \div 175 \times 100=9.71$ \\
\hline B- & 3 & $3 \div 175 \times 100=1.71$ & 2 & $2 \div 175 \times 100=1.14$ & 0 & $0 \div 175 \times 100=0$ & 1 & $1 \div 175 \times 100=0.57$ \\
\hline $\mathrm{AB}+$ & 3 & $3 \div 175 \times 100=1.71$ & 4 & $4 \div 175 \times 100=2.28$ & 0 & $0 \div 175 \times 100=0$ & 4 & $4 \div 175 \times 100=2.28$ \\
\hline AB- & 0 & $0 \div 175 \times 100=0$ & 0 & $0 \div 175 \times 100=0$ & 0 & $0 \div 175 \times 100=0$ & 1 & $1 \div 175 \times 100=0.57$ \\
\hline $\mathrm{O}+$ & 14 & $14 \div 175 \times 100=8$ & 22 & $22 \div 175 \times 100=12.57$ & 1 & $1 \div 175 \times 100=0.57$ & 15 & $15 \div 175 \times 100=8.57$ \\
\hline O- & 0 & $0 \div 175 \times 100=0$ & 5 & $5 \div 175 \times 100=2.85$ & 0 & $0 \div 175 \times 100=0$ & 5 & $5 \div 175 \times 100=2.85$ \\
\hline
\end{tabular}




\section{Project design}

Subject visited different places and surveyed blood grouping. And subject correlated the Rasgulla liking with blood group system. And subject got the different results from different blood groups. Total of 175 subjects were participated. The subjects were students in Bahauddin zakariya university Multan, Pakistan.

\section{Statistical analysis}

Statistical Analysis was performed by MS Excel.

\section{Results and discussion}

Association of Rasgulla likeness with blood Grouping.

Rasgulla likeness with blood Grouping is given in Table 1. Questionnaire based studies have given an important advancement in recent researches. Japan was the only country who checked the relationship of Rasgulla likeness with Blood Grouping. ${ }^{3-10}$

\section{Conclusion}

It was concluded from the present study that actual or findings of us were, Maximum percentage of Male Blood Grouping was in $\mathrm{O}^{+} \mathrm{ve}$ and it was $8 \%$. Maximum percentage of Female Blood Grouping was in $\mathrm{B}+\mathrm{ve}$ and it was $9.71 \%$.

\section{Acknowledgments}

None.

\section{Conflicts of interest}

Author declares that there is no conflicts of interest.

\section{References}

1. Qadir MI, Malik SA. Comparison of alterations in red blood cell count and alterations in hemoglobin concentration in patients suffering from rectal carcinoma undergoing 5-fluorouracil and folic acid therapy. Pharmacology online. 2010;3:240-243.

2. Qadir MI, Noor A. Anemia's. Rare \& Uncommon Diseases. Cambridge Scholars Publishing. Newcastle, England. ISBN. 2018; 978-1-52751807-0.

3. Qadir MI, Javid A. Awareness about Crohn's Disease in biotechnology students. Glo Adv Res J Med Medical Sci.2018;7(3):062-064.

4. Qadir MI, Saleem A. Awareness about ischemic heart disease in university biotechnology students. Glo Adv Res J Med Medical Sci.2018;7(3):059-061.

5. Qadir MI, Ishfaq S. Awareness about hypertension in biology students. Int J Mod Pharma Res. 2018;7(2):08-10.

6. Qadir MI, Mehwish. Awareness about psoriasis disease. Int J Mod Pharma Res. 2018;7(2):17-18.

7. Qadir MI, Shahzad R. Awareness about obesity in postgraduate students of biotechnology. Int J Mod Pharma Res. 2018;7(2):14-16.

8. Qadir MI, Rizvi M. Awareness about thalassemia in post graduate students. MOJ Lymphology \& Phlebology. 2018;2(1):14-16.

9. Qadir MI, Ghalia BA. Awareness survey about colorectal cancer in students of M. Phil Biotechnology at Bahauddin Zakariya University, Multan, Pakistan. Nov Appro in Can Study, NACS 2018;1(3):NACS.000514. 2018.

10. Qadir MI, Saba G. Awareness about intestinal cancer in university student. Nov Appro in Can Study. NACS. 2018:1(3). 